\title{
ACCRUALS TO DATE OF DEATH FOR INCOME TAX PURPOSES
}

\section{Charles C. Parlin †}

Section 42 of the Revenue Act provides: "In the case of the death of a taxpayer there shall be included in computing net income for the taxable period in which falls the date of his death, amounts accrued up to the date of his death. . . ." I This Section often requires the inclusion in a single return of (a) income up to date of death on a cash receipts basis, plus (b) income accrued to the date of the death. The total of the two amounts is called "net income" for the year and subjected to the surtax rates applicable thereto. This provision, first incorporated in the Revenue Act of 1934 , is continued in the 1936 and r938 Acts.

The reason for the provision is manifest. It was the practice to accrue all income to date of death and report such accrual in the federal estate tax return as a capital item existing at the date of death. When the income was subsequently received by the executor, it was received not as income but as a return of capital free from income tax. ${ }^{2}$ Thus, items of income which had accrued at the date of death were subjected to estate tax but entirely escaped income tax. To remedy this, the new Section made a bold attempt to require the computation of "income" on an accrual basis for a taxpayer who in life had kept his books on a cash basis.

This raises a series of questions. Does the Sixteenth Amendment, authorizing a tax on "incomes from whatever source derived", 3 mean income computed on a cash basis, on an accrual basis, on the basis on which the taxpayer elects to keep his books or on such basis as from time to time Congress or the commissioner may prescribe regardless of how the taxpayer elects to keep his books? Even if Congress has the power to prescribe a method for computing income, can it, within the scope of the Sixteenth Amendment, require that a taxpayer file a return including all income on a cash basis, superimpose upon such income additional items computed on an accrual basis, and subject the composite of these two items to the steep surtax rates now in force? As a matter of statutory construction, to what extent do items not susceptible

$\doteqdot$ B. S. in E., I919, University of Pennsylvania ; LL. B., rg22, Harvard Law School; member of the New York Bar.

r. 48 STat. 694,26 U. S. C. A. $\$ 42$ (1934); 49 Stat. I666 (r936), 26 U. S. C. A. $\S 42$ (Supp. I9.37) ; Revenue Act of I938, Pub. L. No. 554, 75th Cong., 3d Sess. (May 26, 1938), 26 U. S. C. A. \$ 42 (Sunp. I9:3).

2. Bull v. United States, 295 U. S. 247 (I935) ; Nichols v. United States, 64 U. S. Ct. Cl. 24 I (I927), cert. denied, 277 U. S. 584 (I928).

3. U. S. Const. Amend. XVI. 
of "accrual" on a straight time-elapsed basis represent "amounts accrued up to the date of death"?

\section{History of the "Accrual Basis"}

The use of the word "accrual" in connection with an accounting system apparently developed in the Treasury Department. There is no prior historical sanction in the field of law or accounting. Bouvier's Law Dictionary, for example, gives no reference to accrual in relation to general accounting. ${ }^{4} \mathrm{Mr}$. George O. May has pointed out that the phrase, "accrual accounting", although used by economists in regard to government fiscal plans, was not generally employed by accountants even in governmental matters. 5 There is evidence of this in the records of the proceedings of the First Congress of Accountants held in St. Louis in 1904. Again, there was correspondence between accounting firms and the Attorney General immediately prior to the enactment of the Corporation Excise Tax Law of I909. As opposed to the cash basis, the accountants then advocated a basis of "earnings and expenses"; and, according to Mr. May, throughout the correspondence of that period they used the word "accrue" only in regard to interest. In "Public Finance", by Professor H. C. Addams, published in I898, where the author discusses the relative advantages of cash and accrual methods of accounting for governmental purposes, Mr. May finds the first use of the term. Prior to the income tax era, "accrual" apparently applied only to interest.

The Income Tax Act of $1870,{ }^{6}$ the Income Tax Act of $1894,{ }^{7}$ the Corporate Excise Tax of $1909^{8}$ and the Income Tax Act of $19 \mathrm{I} 3{ }^{\circ}{ }^{9}$ all provided for computation of tax on a cash basis. The I9r6 statute ${ }^{10}$ for the first time offered the taxpayer the option of the accrual method. The I918 statute ${ }^{11}$ for the first time made the accrual method obligatory if the books of the taxpayer were kept on that basis, but the taxpayer still had an option as to how his books should be kept. Subsequent enactments made the use of the accrual method obligatory if, in

4. "To grow; to be added to; to become a present right or demand, as the interest accrues on the principal. Accruing costs are those which become due and are created after judgment ; as the costs of an execution."

"To rise, to happen, to come to pass; as the statute of limitation does not commence running 'until the cause of action has accrued. A cause of action accrues when suit may be commenced for a breach of contract. It is distinguished from sustain; and from owing."

5. May, Accrual Accontuting and Reserves in Tax Practice (I925) 40 Journal of Accountancy 470 (letter to editor).

6. I6 STAT. 256 (I870).

7. 28 STAT. 553 (I894).

8. 36 Stat. II2 (I909).

9. 38 Stat. I68 (IgI3).

Io. 39 Stat. 756 (I9r6).

II. 40 STAT. I057 (I919), 34 U. S. C. A. § 360 et seq. (1934). 
the opinion of the commissioner, such method was necessary to indicate properly the income of the particular business regardless of the bookkeeping method used by the taxpayer. ${ }^{12}$

With increasing confidence Congress in the Revenue Act of $1934^{13}$ pressed the point one step further: the return of a decedent for the period ending with date of death must include income "accrued", even though the books of the decedent were kept on a cash basis and even though a cash basis, under the rules prescribed by the commissioner, had up to the point of death adequately reflected the income of the decedent.

\section{Constitutionality}

That Congress approached the accrual system cautiously is understandable. At the time the Sixteenth Amendment was proposed, there was ground for belief that "income" meant a computation on the cash basis. The Income Tax Act of July I4, I87o imposed a tax on "gains, profits and income". ${ }^{14}$ In United States $v$. Schillinger ${ }^{15}$ the court held that promissory notes received in part payment on the sale of patent rights did not constitute income in the year of receipt, saying:

"In the absence of any special provision of law to the contrary, income must be taken to mean money, and not the expectation of receiving it, or the right to receive it at a future time." 16

The Corporation Excise Tax of Igog (in spite of the protests of the accountants, referred to above) provided for computation of tax on the basis of receipts and disbursements. In commenting on this phase of the Act, the District Court of New Jersey, in Mutual Benefit Life Ins. Co. v. Herold, ${ }^{17}$ said:

"The language seems clearly to indicate that the net income, which is the measure of taxation, means what has actually been received, and not that which, although due, has not been received, but its payment for some reason deferred or postponed.

Furthermore, the word 'income' means, as already shown, that which has come in, and not that which might have come in, but did not."18

12. E. g., the commissioner fourd that the cruise and tourist business did not adapt itself to the cash basis. Money received from tickets was subject to refund if the cruise or tour was not run; the expense of getting up and carrying out the cruise often fell in a different period than the receipts. In spite of the fact that the taxpayer was content to keep his books on the cash basis, the commissioner required him to report on the accrual basis. I. T. 2080, III-2 CUM. Bull. 48 (I924).

I3. 48 Stat. 694, 26 U. S. C. A. \$\$ 42-43 (I934).

14. I6 Stat. 256 (I870).

15. 27 Fed. Cas. No. 16, 228 (C. C. S. D. N. Y. 1876).

16. Ibid.

I7. I9S Fed. I99 (D. N. J. I9r2).

I8. Id. at 214. 
Certainly it is too late now to argue that a computation on the accrual basis gives a figure not "income" within the meaning of the Sixteenth Amendment. In the first place, economists, lawyers and accountants would all agree that true "income" can in most cases be determined more accurately on the accrual basis than on a strictly cash basis. In the second place, the Supreme Court has considered and decided too many cases involving problems of accruals now to make possible a challenge of the entire system although there appears to be no opinion specifically dealing with the point. In United States $v$. Anderson ${ }^{19}$ the Supreme Court had under review a return involving the r9I6 Act in which the taxpayer had elected to be taxed on the accrual basis. The Court settled a conflict as to whether the munitions tax, which was paid in I9I7, was a deduction for I9I6 or I9I7. In United States v. American Can $\mathrm{Co}^{20}$ the Court again had before it a return involving the I9I6 Act in which the taxpayer had elected to use the accrual basis. The company kept its inventories on the theory of "base stocks". The commissioner accepted the accrual method but held that the "base stock" was unsound inventory accounting and rewrote the inventories. The company argued that under the I9I6 Act the commissioner must accept the accounting system in fact used, or, if this was found by him to be improper according to his standards, the commissioner's only alternative was to accept the cash basis. The Court rejected this and allowed the commissioner to hold the company to the accrual basis and make corrections in the inventory method. In the opinion, however, the Court expressly points out that the company had elected to have its tax computed on the accrual basis. A month later the Court of Claims, in Weed Bros. $v$. United States, ${ }^{21}$ rejected a taxpayer's claim for refund of tax paid under the IgI 8 Act, said that the accrual method was constitutional, and cited the Anderson case. No reference is made to the fact that in the Anderson case the taxpayer had elected to use the accrual method. Of course, in the Weed Bros. case, since the I9I8 Act was involved, the taxpayer would have had to elect to keep his books on a cash basis in order to have his tax so computed; but the question of election was not considered. The Supreme Court denied certiorari in the Weed Bros. case, ${ }^{22}$ and since then lawyers and the courts have apparently taken for granted the propriety of the accrual system.

Section 42 has not yet reached the Supreme Court. By requiring the inclusion of (a) cash receipts and (b) accruals in a single return for the period ending with death, the total gives a figure that certainly

I9. 269 U. S. 422 (I926).

20. 280 U. S. 4 I2 (I930).

21. 69 U. S. Ct. Cl. 246 (1930).

22. 282 U. S. 846 (1930). 
is not "income" for the particular period covered by the return. It is difficult to see how an economist, lawyer or accountant could work out a satisfactory definition of "income" which would include the nondescript figure shown as "net income" on the decedent's return. The Bureau apparently recognizes and faces the fact that under Section 42 , income for more than the period covered by the return is, in fact, consolidated into such return. ${ }^{23}$

If, as appears to be the case, Congress has by arbitrary formula arrived at a figure which is not "income" for the particular period in any recognized economic, legal or accounting sense, how can the Government justify the tax under the Sixteenth Amendment?

They may argue that the particular return involved is for less than a calendar year-an arbitrary period defined by Congress which begins with the taxpayer's fiscal year and ends with date of death; that, having defined a short period for this return, Congress can define what "income" shall be included in it; that the case is governed by Guaranty Trust Co. v. Commissioner. ${ }^{24}$ In this case Fleming during his lifetime reported on the cash basis for the calendar year. He died December 16, 1933. At the time of his death he was a member of a partnership which reported on a cash basis for the fiscal year ended July $3 I$, I933. His death caused a dissolution of the partnership, and the partnership closed its books and made an accounting as of December I6, I933. The commissioner included in the deceased's return for the period January I to December I6, I933, (a) the deceased's interest in the income of the partnership for the twelve months ended July $3 \mathrm{r}$, and (b) the deceased's interest in the partnership earnings for the four and a half months' period ended December I6. The executor argued that this meant that sixteen and a half months of partnership income was in fact being taxed in one year under the rates applicable to a single year's income and that this resulted in paying surtaxes in the 50 per cent. brackets, whereas 29 per cent. brackets would have been a maximum on the correct basis. The Circuit Court of Appeals for the Second Circuit and the Supreme Court both upheld the commissioner. The courts held that under the statute there were two "partnership years" ending in one taxable year of the decedent, but that this did not make the taxpayer include his income for more than twelve months. In computing the taxpayer's income, they found it proper to include the distributive share of a partnership accounting period or periods regardless of the fact that the partnership books may have been kept on a different basis or that the partnership period or periods were not co-extensive with the taxpayer's taxable year. Mr. Justice Stone said: 
"Receipt of income or accrual of the right to receive it within the tax year is the test of taxability, not the time it has taken the taxpayer to earn it nor the duration of his investments which have finally resulted in profit." 25

It may prove to be significant that, in referring to the test of taxability, the Supreme Court used the terms "receipt of income" and "accrual of the right to receive income" in the alternative. Section 42 will bring the test of the right to compute income by a combination of the two theories. ${ }^{26}$ The Government will undoubtedly argue that Congress has the power to tax income; that the income was the income of the decedent; that Congress can make its own determination of period just as it has the right to determine who shall pay the tax under Taft $v$. Bowers. $^{27}$ In upholding the right of the Government to tax to the donee the full gain on the sale of securities computed on the basis of the donor's cost, Judge Learned Hand said when this case was in the circuit court of appeals:

"I am not concerned for the moment with whose gain it is, but that the whole gain is income can not, I submit, be disputed. If it is important, I suggest that the language of the Amendment itself gives Congress power to lay 'taxes on incomes' not on persons." 28

In connection with Section 42 , the courts will undoubtedly be urged to adopt a view that both the cash receipts and the accruals are "income" and, therefore, the courts are not concerned for the moment as to who pays the tax or for what particular year or taxable period the tax is computed and levied.

The adoption of any such view will require courts to go further than they have yet gone. "Income" does not exist in the abstract as of a given date. "Income" has significance only as computed in terms of a known and specified period. The annual accounting period has been spoken of as "one of the corner-stones of our tax structure", ${ }^{29}$ and many times has been referred to by the courts as a fundamental con-

25. Id. at 498 (italics supplied).

26. Guaranty Trust Co. v. Commissioner, 303 U. S. 493 (1938). The case involved the year 1933 and therefore Section 42 was not in litigation, but the Government in its brief before the Supreme Court makes the following reference to the section (page $3 \mathrm{I}$ ):

"The revenue acts now recognize that even non-partnership income must be treated differently in the taxable year of a taxpayer's death than if he had lived through all of that year. Section 42 of the Revenue Act of 1934 provides that amounts accrued up to the date of death of a taxpayer shall be included in computing net income if not otherwise includable. As a result of this section a taxpayer on a cash basis is taxed during the year of his death on income on which he would not be taxed until the following year if he had lived. It is his income, however, during the year in which he died."

27. 278 U. S. 470 (I929).

28. 20 F. (2d) $56 \mathrm{I}, 564$ (C. C. A. 2 d, 1927 ).

29. R. W. Archbald, Jr., 4 B. T. A. 483,485 (1926). 
cept. $^{30}$ The Supreme Court has granted certiorari and passed judgment in too many cases involving a conflict as to the particular year in which an item of gross income was to be included, or the year in which a particular deduction was to be taken, to permit of any sweeping generality that income is income and it is unimportant as to the year in which it is to be taxed.

In Hoeper v. Tax Commission of Wisconsin ${ }^{31}$ the Court held unconstitutional that part of the Wisconsin income tax which forced a joint return by husband and wife and the computation of a tax on the joint income at the graduated rates. Mr. Justice Roberts said:

"That which is not in fact the taxpayer's income can not be made such by calling it income." 32

It must be noted, however, that this case was decided in I93I and that Justices Holmes, Brandeis and Stone dissented.

\section{Determination of Accruals}

In spite of the frequent reference to "the accrual basis", there is, of course no one system. ${ }^{33}$ Out of the myriad items that go into the computation of gross income and the deductions to be taken in computing the net income, there is wide latitude for argument on law and on accounting practice, and wide scope for differences of opinion on matters of business judgment.

The Treasury Department has recognized the necessity for allowing considerable latitude. For example, Regulations 94, Article 4I-2, ${ }^{34}$ provides that any approved standard method of accounting will ordinarily be regarded as clearly reflecting income. Even bad accounting practice, if consistently followed by the taxpayer, will be tolerated to a certain extent. ${ }^{35}$

Section 42 apparently requires for the first time the establishment of a system. The decedent presumably kept his books on a cash basis. There is no way, therefore, in which the commissioner can, on the basis of prior usage, be lenient as to use of accounting methods or tolerant as

30. See Lucas v. American Code Co., Inc., 280 U. S. 445 (1930); Burnet v. Sanford \& Brooks Co., 282 U. S. 359 (I93I) ; Burnet v. Thompson Oil \& Gas Co., 283 U. S. 3or (I93I) ; Helvering v. Morgan's Inc., 293 U. S. I2I (1934).

3I. 284 U. S. 206 (I93I).

32. Id. at 215 .

33. May, Taxable Income and Acconnting Bases for Determining It (I925) 40 JOURNAL OF ACCOUNTANCY 248.

34. U. S. Treas. Reg. 94, Art. 4I (I936).

35. U. S. Treas. Reg. 94, Art. 43 at I47 (1936), provides: "It is recognized, however, that particularly in a going business of any magnitude there are certain overlapping items both of income and deduction, and so long as these overlapping items do not materially distort the income they may be included in the year in which the taxpayer, pursuant to a consistent policy, takes them into his accounts." 
to overlapping items. Apparently the commissioner plans to prescribe the rules for accruing and has adopted Magill's definition:

“. . . Income can be said to have been realized on an accrual basis upon (I) the completion of those operations on the part of the prospective recipient, for which the money or money equivalent is to be paid; plus (2) the happening of a sufficient number of events to make it reasonably probable that a determinable amount of money or its equivalent will in fact be paid in due course of business." 36

In the case of interest, rent, salary, and the like, where there is no problem other than a mathematical computation based on the number of days elapsed, there can be no dispute as to the accrual. But in the other cases, what is a "determinable amount of money" and when is it "reasonably probable" that it will in fact be paid?

The commissioner is taking the position that whenever the amount of ultimate receipt is possible of estimate the requirements have been met. Thus in any case where the decedent has rendered services or performed work, whether or not completed at date of death, for which compensation will eventually be received by the estate, the amount of compensation may be estimated; and the amount of such estimate taxed as an "accrual" of income at date of death. The application of this theory will undoubtedly produce a volume of litigation.

The question of when an item is "accrued" is a mixed question of fact, law and sound accounting practice. It is interesting to note that Magill, after referring to the attempts to define accrual of income, says, in submitting his definition: "The point is attended with much difficulty, and any conclusion is open to attack . . ." 37 In a footnote, he compares his definition with that of Canning:

"Most commonly the fruition will be considered to have occurred when that stage of a particular kind of operation has been reached at which all the following conditions are fulfilled: (I) the future receipt of money within one year has become highly probable; (2) the amount to be received can be estimated with a high degree of reliability; (3) the expenses incurred or to be incurred in the cycle can be estimated with a high degree of accuracy." 38

The courts to date have given no decisive definition. In general they have refused to allow the commissioner to tax income as accrued, or to allow the taxpayer an accrued deduction, where something remains to be done with respect to the creation of the income or the expense, or

36. Magill, Taxable Income (1936) i8o.

37. Ibid.

38. Canning, The Economics of Accountancy (i933) I03. 
where the right to receive income or deduct expenses is contingent upon the happening of future events. ${ }^{39}$ In Schoellkopf Aniline \& Chemical Works, Inc. v. United States ${ }^{40}$ the Court of Claims said:

"An item accrues when all events have occurred necessary to fix the liabilities of the parties concerned therewith and to determine the amount of such liabilities. There must not only be admitted liability arising on account of the transaction, but also the events necessary to fix the amount of the liability must have occurred." 41

The scope of this paper does not make possible a study of the problems of accruals generally, but will permit a brief consideration of a few of the specific problems which must inevitably find their way to the courts.

\section{Partner's Interest in Partnership}

With very few exceptions, individuals report for income tax on a cash basis. If the partnership is on an accrual basis, presumably the partnership income can be accrued to date of the partner's death and the share of the deceased partner in such accrual can be computed. But is such share income accrued to the deceased? This would seem to depend on whether, under the applicable law and the partnership articles, the partnership terminated on the death of the partner. If it did terminate, the return for the period ending with death would include the share of the partnership income because a taxable year of the partnership ended within the period of the return. ${ }^{42}$

But if the partnership did not terminate with death, or if the partnership is on a cash basis, the share of the income of the partnership accrued to date of death cannot be included in the decedent's return unless Section 42 cuts through the partnership and permits the accrual of partnership income directly as though it were the income of the individual.

There is little to justify such a construction of Section 42 . The acts containing this Section make no changes with reference to partnerships, and partnerships have now been effectively established as "tax

39. Lucas v. American Code Co., 280 U. S. 445 (I930); Lucas v. North Texas Lumber Co., 28I U. S. Ix (I930); Burnet v. Logan, 283 U. S. 404 (I93I); North American Oil Consolidated v. Burnet, 286 U. S. 4 I7 (1936); Lichtenberger-Ferguson Co. v. Welch, 54 F. (2d) 570 (C. C. A. 9th, I93I); United States v. Utah-Idaho Sugar Co., 96 F. (2d) 756 (C. C. A. roth, I938).

40. 3 F. Supp. 4I7 (1933).

4I. Id. at 42r. Compare the language of the Supreme Court in United States v. Safety Car Heating \& Lighting Co., 297 U. S. 88, 99 (I936) : "Income within the meaning of the Sixteenth Amendment is the fruit that is born of capital, not the potency of fruition." See also: Burnet v. Logan, 283 U. S. 404 (I93I) ; Spring City Foundry Co. v. Commissioner, 292 U. S. I82 (1934); Lichtenberger-Ferguson Co. v. Welch, 54 F. (2d) 570 (C. C. A. 9th, I93I) ; United States v. Utah-Idaho Sugar Co., 96 F. (2d) 756 (C. C. A. Ioth, 1938).

42. Guaranty Trust Co. v. Commissioner, 303 U. S. 493 (I938). 
computing units", separate and distinct from the individual partners. The Government cannot levy on partnership assets because of a tax claim against an individual partner ; ${ }^{43}$ a partner cannot offset personal non-capital losses against his distributive share of partnership noncapital gains; ${ }^{44}$ the partners and their partnership can have different fiscal years; ${ }^{45}$ the partners and their partnership can have different methods of accounting. ${ }^{46}$

The cases last cited all hold that the partners can report on a cash basis even though their partnership continues to report on an accrual basis. The converse would seem to follow. A partnership properly on a cash basis ( this basis even though Section 42 has forced one of the partners to an accrual basis.

If this is true, it follows that the return for a deceased partner even though on an accrual basis picks up income from the partnership computed on the partnership basis, i. e., on the cash basis. It seems unlikely that the courts will construe Section 42 as permitting the commissioner to force not only the individual but also the partnership from a cash to an accrual basis.

\section{Profit Sharing Agreements}

If the profit sharing agreement calls for current computations and payments on a weekly or monthly basis and, in the case of death of the employee, a computation based on the profit to date of death, there is an obvious basis for claiming that compensation has accrued to the employee at date of death. But in the majority of cases current computations of profits are not possible. Year-end inventories may be essential. In such cases it is not uncommon to provide that the earnings for the company's full fiscal year will be computed and then prorated to date of death and that the profit sharing payment, if any, will be made on this prorated basis.

Such a contract was reviewed by the general counsel in a memorandum. ${ }^{47}$ The employee died in November I934; the company was on a calendar year basis. The contract provided for "a salary" equal to a percentage of the net profits derived from the sale of merchandise in the stores under his management; in case of death the contract should terminate and the employee's estate should share in the profits only up

43. United States v. Kaufman, 267 U. S. 408 (1925).

44. Johnston v. Commissioner, 86 F. (2d) 732 (C. C. A. 2d, I936) ; G. C. M. I40I2, XIV-I CuM. BULL. I45 (I935).

45. Guaranty Trust Co. v. Commissioner, 303 U. S. 493 (I938).

46. Truman v. United States, 4 F. Supp. 447 (E. D. Ill. I933); Percival H. Truman, 3 B. T. A. 386 (I926); W. J. Burns, I2 B. T. A. I209 (I928); Fritz Hill, 22 B. T. A. 1079 (I93I).

47. G. C. M. I6I2r, XV-6 Cum. Bule. I2I (I934). 
to the time of death, "such share to be based upon the total net profits for the year, pro rata for the time served"; the estate was to have no right to settlement until after the annual inventory had been completed, "not later, however, than March I of the succeeding year". The general counsel ruled that, under Section 42 , the amount which was determined and paid in I935 had "accrued" at date of death in November, I934. He said:

"Under the circumstances of the present case, it is evident that the taxpayer had, at the date of his death, become legally entitled to receive a certain share of the net profits derived from the sale of merchandise in the stores under his management for the year 1934, to be computed by prorating the total net profits for the year upon the basis of the time served by him in such year prior to his death. Only the exact amount of his share of the profits remained to be determined." 48

This ruling is indicative of how far the Government will go in claiming "accruals" at date of death, but the soundness of such practice is open to question. Under the contract, it was not certain, as of date of death, that anything would be due. Operating losses for the balance of November and the month of December and year-end inventory losses might have exhausted the apparent profits up to date of death leaving no net profit for the year. The services had all been rendered; an obligation to pay according to an agreed formula had become fixed; but the amount of the payment, if any, could at best be estimated. With the amount of payment, if any, contingent upon results of continued operation, it seems doubtful whether there was an accrual within the scope of recognized accounting practice. Furthermore, this ruling seems inconsistent with the regulations dealing with compensation for services, which have consistently provided that "the amount received is income for the taxable year of its determination, if the return is rendered on the accrual basis." 49

In Fehrman v. Commissioner ${ }^{\mathbf{5 0}}$ what appears to be the same contract came before the Board of Tax Appeals. The decedent had been an employee of the Woolworth Company and had died August I4, I934. Under the terms of the contract additional compensation was computed at the end of the year I934 and actually paid in January of I935. The Board held that, so far as this additional compensation was concerned, there had been no "accrual" on August I4, I934:

"If petitioner's decedent had been on an accrual basis rather than a cash basis, would the amount paid to petitioner by the $\mathrm{F}$.

48. Id. at I22.

49. U. S. Treas. Reg. 94, Art. 42 (I) ; id. 86, Art. 42 (I) ; id. 77, Art. 33I ; id. 74, Art. 331 ; id. 69 , Art. 32 ; id. 65 , Art. $32 ;$ id. 62 , Art. 32 ; id. 45, Art. 32.

50. 38 B. T. A. No. 7 (July I2, I938). 
W. Woolworth Co. in January 1935 be properly considered as income accrued to the decedent at the date of his death? It is our opinion that it would not." 51

\section{Insurance Agents}

So long as the test is that it is "reasonably probable that a determinable amount of money" will be paid in the future, the commissioner will undoubtedly hold that the full amount of renewal premiums to be received in the future constitute accrued income. The commissioner will find some support in Brown v. Helvering. ${ }^{52}$

In the case of life insurance policies the agent usually receives a commission on a policy at the time of issue and further commissions from time to time as the insured pays premiums for subsequent years. If the policy is terminated by death or for any reason cancelled, the agent receives no further payments. In a memorandum by the general counsel ${ }^{53}$ it was held that in case of the death of an insurance agent the proper method under the Revenue Acts of I926 and I928 was for the executor to report as a capital item, existing as of date of death for purpose of estate tax, the estimated value of the contract rights to future payments then existing and to report as income in subsequent periods only the amount by which actual receipts exceeded this estimate. This ruling also appears to support the propriety of "accruing" some amount as of date of death.

Under the bankruptcy law, it has been held that upon an insurance agent's becoming bankrupt, the trustee in bankruptcy takes over the renewal commissions on policies written prior to the bankruptcy. ${ }^{54}$

On the other hand, the question arose under the earlier acts in respect to policies which had been issued prior to March I, I9I 3 and on the basis of which agents had received instalments of commission out of subsequent annual premium payments. The Circuit Court of Appeals for the Seventh Circuit ${ }^{55}$ and the Circuit Court of Appeals for

5I. $I d$. at 6.

52. 291 U. S. 193 (I933). In this case the taxpayer was a general agent and received "over-riding commissions" on fire insurance policies which were written for periods of one, three or five years, with the right of cancellation by either party at stipulated rates of premium return. The taxpayer's books were kept on an accrual basis and the full amount of the premium to be received was recorded at the time the policy was written. At the end of the year he set up on his books a reserve entitled "Return Commission", which represented his estimate of the amount of commissions which he would have to refund because of cancellations of policies. This reserve was based upon an average experience over a period of years. The Supreme Court upheld the commissioner in treating the full premiums recorded on the books at the time the policies were written as income on an accrual basis and allowed as a deduction only the amount actually paid out by way of refunds on actual cancellations.

53. G. C. M. II473, XII-I Cum. Bull. gI (r928).

54. In re Wright, I57 Fed. 544 (C. C. A. 2d, I907); Equitable Life Assurance Soc. v. Steward, I2 F. Supp. I86 (W. D. S. C. I935).

55. Workman v. Commissioner, 4I F. (2d) I39 (C. C. A. 7th, 1930). 
the Third Circuit ${ }^{56}$ both held that the contractual rights to receive future payments as they existed on March I, I9I3 were too contingent to afford the immunity from income tax in subsequent years; consequently the full amuunt of the cash received by the insurance agent in subsequent years constituted taxable income. Both courts pointed out in detail the two contingencies existing on March I, I9I3; namely, (a) that the particular policy might mature through the death of the decedent, or (b) that the insured should forfeit the policy by failure to pay subsequent premiums. The language of these two cases gives strong indication that those courts would not consider the future premiums "accrued".

What appears to be the first case on the point has gone in favor of the taxpayer. The United States District Court for the Western District of Washington ${ }^{57}$ held that the value of decedent's right of expectancy on account of commissions which policyholders might pay after his death, but were not obligated to pay, did not constitute accrued income to decedent under Section 42.

\section{Attorneys}

Generally speaking attorneys' fees have not been considered as accruable either from the standpoint of the client or the attorney. There may be some cases in which the amount of an annual or monthly retainer can be accrued the same as any salary or rent payment. Likewise there may be a proper basis for accrual if the particular legal job has been completed, the amount of fee has been agreed upon with the client, and payment is merely delayed. The difficult problems arise in cases where work is still in progress and where the ultimate fee has not been determined.

$U_{p}$ to the adoption of the Revenue Act of I934, the commissioner had consistently taken the position that attorneys' fees were not accruable. In $A . R$. R. 702,58 the Committee on Appeals and Review had before it the return of a law partnership which had kept its books and made its returns on an "accrual" basis, but had applied for permission to change to a cash basis for the year I920. It was the practice of the firm at the conclusion of a job to enter in its books a charge for services in an amount considered by it to be just and appropriate. The facts showed that in many cases the ultimate fee was different in amount from the figure entered in the books. The Income Tax Unit had denied permission to change to the cash basis. The Committee found that

56. Woods v. Lewellyn, 252 Fed. 106 (C. C. A. 3d, 1918).

57. Seattle First Nat. Bank v. Hendrickson, 24 F. Supp. 256 (W. D. Wash. 1938).

58. I-I Cuar. Bull. 47 (Ig22). 
there was no standard fixed for the determination of the value of legal services and that the mere rendition of legal services was not a sufficient basis for fixing their value. In reversing the Income Tax Unit and recommending that net income of the law firm for the year I920 and subsequent years be computed on a cash basis, ${ }^{59}$ the Committee said:

"In view of the foregoing facts the Committee is of the opinion that the method used by the appellant in determining its net income for the taxable year 1920 is not sufficiently definite to be construed as clearly reflecting the income of the firm, that the method used is not an accrual method in its acknowledged sense, and that the computation of net income for the year 1920 is more correctly determinable on the basis of cash receipts and disbursements." 60

However, Treasury Department audits of taxpayer's returns are currently being made on the basis of "accruing", as of date of death, an amount equal to the estimated attorneys' fees to be received by the estate in the future. The agents are going to the extent of "accruing" to a partner his share of partnership fees likewise "accrued" to date of death even though the partnership is on a cash basis. As authority for such action, the Bureau has maintained: (a) that all the "operations on the part of the prospective recipient" have been performed because whatever payments will be received in the future by the executor are obviously for services performed by the deceased attorney in his lifetime, and (b) it is "reasonably probable that a determinable amount of money" will be received. In support of this practice of estimating the fees to be received in the future, the Bureau calls attention to the custom, prevalent among executors, of including in the estate tax return (following the practice outlined in the Nichols case and G. C. M. I $\left(473^{61}\right.$ ), an estimated amount of the fees to be received by the attorney's representatives, whether the attorney had his own practice or was a member of a law partnership.

Most law firms make some provision for giving to the estate of a deceased partner some share in the fees received after the partner's death but covering work commenced by the firm prior to death. The exact methods vary. One firm, for example, allocates each such fee between the old firm (of which the deceased was a member) and the new firm (of which he was not a member) on the relative number of days elapsed from the beginning of the particular job to date of death and elapsed from the date of death to the completion of the job. Another firm makes such allocation after review by the senior members of

59. To same effect: A. R. R. 6158, III-I Curr. BuLr. 75 (I924).

6o. A. R. R. 702, I-I Cum. Burt. 47, 49 (I922).

6I. XII-I Cum. Bull. 9I (1933). 
the firm and a determination of what allocation is equitable under the circumstances. Another firm makes the allocation on the basis of the number of hours spent by lawyers on the case prior to date of death and after date of death. The commissioner, however, says that regardless of method and regardless of how long it will take to collect the fees on the work commenced by the partnership prior to death, the estimated amount is "accrued" at date of death.

The cases dealing with receipt of fees by attorneys have consistently applied the rules applicable to a computation of income on a cash basis. $^{62}$ A study of the text of these cases discloses nothing to give encouragement to the commissioner's proposition that attorneys' fees generally can be "accrued".

From the standpoint of the client, it has been decided that a deduction can be had for attorneys' fees in the year of "accrual" or in the year in which "paid", depending upon the basis on which the client's books were kept. $O . D \cdot 3^{63}$ is to this effect, but there is no indication of how to determine when a legal fee is accrued. In Searles Real Estate Trust $v$. Commissioner ${ }^{64}$ the taxpayer had filed its return on a cash basis, but the commissioner held that an accrual basis was called for and in this was sustained by the Board. The taxpayer claimed that, if its income was to be computed on an accrual basis, it was entitled to a deduction for legal fees in the amount of $\$ 446$ for the year I922 and in the amount of $\$ 454$ for the year I923. The evidence shows that the services had been rendered in the years in question, that the amounts had been agreed upon and that the law firm which had rendered the services had entered these amounts in the firm's books and had sent out the bills although the sums were not paid until a subsequent time. The Board allowed the deduction of these fees as proper accruals.

In Appeal of New Process Cork $C_{0 .}{ }^{65}$ the taxpayer kept its books on an accrual basis. It was involved in litigation which commenced in I92I and was completed in I922. At the end of I92I, apparently without consultation with the attorneys, a reserve of $\$ \mathrm{I}, 000$ was set up for legal expense and taken as a deduction. The fee for the case, which was billed in 1922 , was $\$ \mathrm{I}, 500$. In disallowing the deduction of the "accrual" for Ig2I, the Board said:

"The item of $\$ 1,000$ sought to be deducted as a legal fee is clearly not deductible. The mere fact that services had been per-

62. Duffin v. Lewis, 55 F. (2d) 786 (C. C. A. 6th, 1932), cert. denied, 287 U. S. 6II (I932); Sutton v. Commissioner, 95 F. (2d) 845 (C. C. A. Ioth, I938); Carey Van Fleet, 2 B. T. A. 825 (1925) ; J. M. Butler, Ig B. T. A. 718 (1930); Sara R. Preston, 35 B. T. A. 312 (1937).

63. I Curr. BuLt. IO9 (I9I9).

64. 25 B. T. A. III5 (I932).

65. 3 B. T. A. 1339 (1926). 
formed does not establish an accrual of an amount erroneously estimated to be the probable compensation which would be payable therefor." 66

In Crozen Cork \& Seal Co. $v$. United States ${ }^{67}$ the court again rejected a deduction for estimated legal fees. The court quoted with approval the Board of Tax Appeal's statement given above and added:

"There was no arrangement or contract with regard to the fee. The services were for the entire case and were not divided and were not divisible. The taxpayer did not have any knowledge or information during I92I nor until it received the bill on April 2 I, I922 as to what the charge would be." 68

As to legal services rendered prior to March I, I9I3 it has been ruled that there was no "accrual" of compensation if the work was finished and paid for after such date. ${ }^{69}$ The full fee constituted taxable income when received.

If an attorney becomes bankrupt, can the trustee in bankruptcy take the fees, or part of the fees, in respect of cases pending at the time of the bankruptcy? It is settled that, if the case is being handled on a contingent fee basis, the trustee in bankruptcy has no right in the matter and the attorney can continue with the case and collect his fee free from creditors. $^{70}$ It seems probable that the same result would follow even if the fee were not strictly contingent.

Every contract for legal services is terminated by the death of the attorney; and whether or not the agreement calls for a contingent fee, the attorney's estate has a valid claim for services on the theory of quantum meruit, not exceeding the rate or sum, if any, fixed. ${ }^{71}$ However, on pending work it is difficult to sustain a claim for any consequential sum. The ultimate success of the work is perhaps the major factor in the determination of legal fees, and the courts have repeatedly stressed this factor in determining fee questions. ${ }^{\mathbf{7 2}}$ With this factor unknown, it seems proper that the client should be charged with only a minimum fee for work to date of death because the client is forced with the necessity of employing another attorney to carry on. There appears to be no authority for "accruing" attorneys' fees due on work unfinished at date of death.

66. Id. at I342.

67. 4 F. Supp. 525 (E. D. N. Y. 1933), aff'd, 73 F. (2d) 997 (C. C. A. 2d, 1934). 68. Id. at 527 .

69. O. D. 956, 4 Cum. Bull. 83 (I921) ; O. D. iाi6, 5 Cum. Buld. ir7 (I92I).

70. In re Coleman, 87 F. (2d) 753 (C. C. A. $2 d$, 1937).

71. Sargent v. McLeod, 209 N. Y. 360, I03 N. E. I64 (IgI3).

72. Woodbury v. Andrew Jergens Co., 37 F. (2d) 749 (S. D. N. Y. I930) ; Shattuck v. Pennsylvania R. R., 48 F. (2d) 346 (W. D. N. Y. I93r) ; Randall v. Packard, I42 N. Y. 47,36 N. E. 823 (I894); Ransom v. Ransom, I47 App. Div. 835 , I33 N. Y. Supp. I73 (Ist Dep't, IgIr). 


\section{Executors}

On audits being currently made by the Treasury Department, it is the practice to include as income accrued to date of death all executors' fees which the decedent's estate may eventually collect. No distinction is made between cases where accountings have or have not been filed prior to the executor's death, or between cases where allowances have or have not been made by the proper court, or between commissions based on principal or based on income.

The cases to date dealing with the year in which an executor must include his fee for income tax purposes all involve executors who are on a cash basis. ${ }^{73}$ A study of the texts gives little help in determining when an executor's fee is "accrued".

Hadden v. Commissioner ${ }^{74}$ involved a New York estate. The Surrogates' Court allowed executors' commissions to the taxpayer in I907, but the taxpayer did not collect the amount till ten years later. The court held this fee was accrued prior to March I, I9I3 and, therefore, not income when received in I9I7. This case is perhaps authority for the proposition that an executor's fee is accrued when it has been allowed by court order.

An early ruling by the Committee on Appeals and Review, based on a solicitor's opinion, goes one step further. ${ }^{75}$ It holds that, under

73. Commissioner v. Cadwalader, 88 F. (2d) 274 (C. C. A. 3d, 1937), cert. denied, Cadwalader v. Commissioner, 301 U. S. 706 (I937), involved the Roebling estate under New Jersey law. In order to secure a deduction for federal estate tax, the executors in I925 gave themselves notes for their fees. On this basis the federal estate tax was closed with these fees as an allowed deduction and on the other hand the executors succeeded in persuading the income tax authorities that the notes did not constitute income for I925. In r930 the accounting was filed and the court made allowance for the executors' fees and the notes were paid. The executors then argued that there was no income in 1930-it should have been taxed in I925 (this was prior to Section 8201) - and the Board accepted the theory. The circuit court of appeals reversed, finding that under the New Jersey statute an executor's fee becomes payable only upon allowance by the court and that the fee was therefore income for that year-1930. Freeman v. United States, 7 I F. (2d) 969 (C. C. A. 3d, I934), cert. denied, 293 U. S. 62 I (I934), involved Pennsylvania law. An executor had rendered services in 1916 and 1917 , but drew down commissions for the two years' work in I9I7 and later in the year filed his intermediate accounts. The court held the full amount to be taxable in I9I7. Faust v. United States, 65 U. S. Ct. Cl. 676 (I928), involved the Adolphus Busch estate under Missouri law. The law allowed a statutory commission of $5 \%$. In I9I4 the plaintiff, who was the deceased's son-in-law, agreed to accept in lieu of statutory commission a flat fee of $\$ \mathrm{r} 50,000$; later he agreed to take no fee; later he changed his mind and asked for the $\$ 150,000$, which he received in IgI7. In Gustav W. Lembeck, I6 B. T. A. 250 (I929), the probate court in r920 had entered an order for the payment of executors' commissions of $\$ 2,917$. There were three executors living at a distance from each other and it was I92I before the three signatures had been obtained and the check of petitioner deposited. The Board held this was I92I income. In Lillie M. Clark, 9 B. T. A. 460 (I927), a deduction for executors' commission was claimed in the estate tax return and allowed by the Bureau. Subsequently, the petitioner waived rights to take a commission and the Board held that no commission having in fact been received there was no income subject to tax.

74. 49 F. (2d) 709 (C. C. A. 2d, I93I).

75. A. R. R. 32r, 3 CuMr. Bulz. I26 (I920). 
the New York law, ${ }^{76}$ whenever the assets were received by the executor prior to March I, I9r3, the one-half of the principal commission due for "receiving" becomes a vested claim and, therefore, when the commission is paid after March I, I9I3, it is not subject to income tax. No mention is made of the order of allowance.

But are these applicable in the case of the death of the executor prior to completion of his duties and prior to the entry of an order of allowance?

The present New York statute covering executors' commissions is Section $285^{77}$ of the Surrogates' Court Act. Except for changes in rates and procedural details, it is in the same form as the old act signed by Governor De Witt Clinton in 1827 .

As to principal, the statute provides that "on the settlement of the account . . . the surrogate must allow" to an executor "for receiving and paying out sums of money" a commission at the prescribed rates. A.R.R. $32 I$ ignored the fact that the statute laid down as a condition to allowance that the executor settle his accounts and that the courts had held that an executor who draws down his commission prior to his accounting is liable for interest on the amount prematurely drawn. ${ }^{78}$ The allowance by the surrogate is not mandatory. The courts have held that commissions may be denied for failing to give personal attention to the estate, ${ }^{79}$ removing funds from a safe to an unsafe bank, ${ }^{80}$ depositing money in a bank account in the fiduciaries' individual names, ${ }^{81}$ unreasonajly delaying payments to a beneficiary, ${ }^{82}$ making or retaining unwise investments, ${ }^{83}$ or because of general negligence. ${ }^{84}$

In the case of a deceased executor the courts have laid down still a further condition to allowance of the commission. The courts have held that an executor who dies prior to completion of his duties is not entitled to statutory commissions as a matter of right but that on the account the surrogate may, in his discretion, make what he regards as a proper allowance, not exceeding the statutory rate. ${ }^{85}$

76. The solicitor in arriving at this conclusion cites: Matter of Roberts, 3 Johns. Ch. 43 (N. Y. I817) ; Matter of Kellogg, 7 Paige 265 (N. Y. 1838) ; Howes v. Davis, 4 Abb. Pr. 7 I (N. Y. I856) ; Ward v. Ford, 4 Redf. 34 (N. Y. 1879) ; Matter of Roosevelt, 5 Redf. 6oI (N. Y. I882) ; Morgan's Estate, I5 Abb. N. C. I98 (N. Y. I885); Matter of Willets, II2 N. Y. 289 , I9 N. E. 690 (I889).

77. N. Y. Crvil PRACTICE ACT (Cahill, I93I) p. 825, § 285 .

78. Dodge, Estate Administration and Accounting (3d ed. I933) 385.

79. Matter of Rutledge, I62 N. Y. 3I, 56 N. E. 5 II (I900).

80. Matter of Scudder, 2r Misc. I79, 47 N. Y. Supp. IOI (Surr. Ct. I897).

81. Matter of Hutkoff, I24 Misc. 703, 209 N. Y. Supp. 588 (Surr. Ct. I925).

82. Matter of Taft, I44 Misc. 896, 259 N. Y. Supp. 887 (Surr. Ct. I932), aff'd on rehearing, 145 Misc. 435, 260 N. Y. Supp. 264 (Surr. Ct. I932).

83. Matter of Lyon, 25I App. Div. 327, 296 N. Y. Supp. 327 (2d Dep't, 1937).

84. Matter of Caffrey, 254 App. Div. 684, 3 N. Y. S. (2d) 443 (2d Dep't, 1938).

85. Matter of Barker, 230 N. Y. 364 , I30 N. E. 577 (I92I). 
In other words, the representative of the deceased executor, in order to collect the receiving commission on such property as was received, and the paying out commission on such property as was paid out, by the executor prior to his death, must (a) render on behalf of the deceased executor an account, (b) satisfy the beneficiaries and the court that the deceased properly discharged his fiduciary duties, and (c) satisfy the beneficiaries and the court that the services actually rendered by the deceased warrant the allowance as requested. The commissioner maintains that in spite of these conditions there is an accrual as of date of death because (I) all the services for which compensation is being paid were rendered prior to death and (2) it is "reasonably probable that a determinable amount of money" will be received. ${ }^{86}$

Perhaps on the annual commissions on income the Government has a stronger case than on the principal commissions although the propriety of an accrual even in this case is not clear. The statute provides that an executor who renders an annual account to the beneficiary may retain out of the income his annual commission; if he does not render such annual account, he is allowed his commission only upon judicial settlement of his account. If it was the custom of the deceased to render annual accounts and currently draw down his income commissions without judicial accountings, and if the representative of the deceased executor sees to it that the annual statement is sent out when next due following the executor's death, the income commission to date of death may be accrued. The amount is possible of exact computation, and it is not clear that the cases giving the surrogate discretionary powers of allowance or disallowance would be applicable to such a case.

\section{Trustees}

In New York, testamentary trustees, administrators and guardians receive compensation, under Section 285 of the Surrogates' Court Act, on the same basis as executors. All of the contingencies outlined above regarding the right of the representative of the deceased executor are apparently applicable. The leading case on the payment of commissions when a testamentary trustee dies before completing his duties is Matter of Bushe. ${ }^{87}$ In this case there were three trustees; one died; the remaining two prepared and filed an account. The surrogate ruled that he would allow the deceased trustee only such amount as he considered proper payment for the services actually rendered by the deceased. The appellate division reversed this ruling on the ground that the deceased was entitled, as a matter of law, to the statutory commissions. The 
court of appeals outlined three possible views: (I) that the trustee, having failed to complete his duties, was entitled to no compensation; (2) that the trustee was entitled, as a matter of law, to one-half commission for receiving and one-half for paying out, to the extent accomplished, but nothing for his representatives having turned over the remaining assets to the survivors; (3) that the surrogate had discretionary power to award or withhold commissions in particular cases or to allow such sum as was reasonable, not exceeding the statutory rates. The court definitely adopted the third view.

Following the principle of this case, the Circuit Court of Appeals for the Second Circuit refused to require that the bankrupt, one of three testamentary trustees, account, make application for allowance of commission and then pay over the commission to the trustee in bankruptcy. ${ }^{88}$ In holding that no part of the testamentary trustee's fee had accrued at date of bankruptcy, Judge Chase said:

"Merely acting as such a trustee is not enough. He must account properly before he is entitled to a cent. Not until he does so account will any part of his prospective allowance have been earned as a matter of law." 89

It seems doubtful whether this court, at least, will hold that fiduciaries' fees specified in the New York Surrogates' Court Act are "accrued" prior to the surrogate's allowance.

\section{Receivers and Trustees in Bankruptcy}

An early ruling ${ }^{90}$ says that, if a receiver is operating a business on a cash basis, he is to deduct receiver's fees when paid; if the books of the business are kept on an accrual basis, receivers' fees are to be deducted when accrued. No rule is stated as to how or when receivers' fees are accrued.

Courts may appoint receivers or trustees (a) on the basis of a stipulated compensation per month, (b) on the basis that compensation will be determined in a subsequent proceeding, or (c) on the basis of a specified monthly allowance with provision that additional allowances, if any, will be considered in a subsequent proceeding. Jackson v. Smietanka ${ }^{91}$ involved the latter case. From I9I 3 to IgI8 Jackson served as receiver for a railroad under an order which allowed him as compensation, $\$ 2,000$ per month, with permission at the termination of his work "to apply for such further compensation as to the court may then

88. In re Furness, 75 F. (2d) 965 (C. C. A. 2d, I935), 83 U. of PA. L. Rev. 522.

89. $I d$. at 966 .

go. O. D. 3, I CuM. Bull. Iog (IgIg).

9I. 272 Fed. 970 (C. C. A. 7 th, I92I). 
appear reasonable and just". In I9I8, upon application, the court allowed him an additional $\$ 100,000$, and this was paid. When the collector claimed that this $\$ 100,000$ was I9r8 income, Jackson went back to the district court and, ex parte, obtained a nunc pro tunc order reciting that the $\$ 100,000$ was additional compensation for services from Igr 3 to $19 \mathrm{r} 8$ inclusive, and making an allocation between each of the years. The court found that Jackson was on a cash basis, and that therefore the $\$ 100,000$ was income in the year of receipt; but by way of dictum, it added that, even if he were on an accrual basis for the prior years, he had no "unpaid allowances for services from which he could have made returns of income accrued". .2

To the extent that compensation is specified in advance at a definite rate, there is undoubtedly an accrual to date of death. There would seem to be no effective distinction between this and a straight salary. But where the allowance is left to the discretion of the court, there can hardly be an accrual within the scope of recognized accounting formulas. A brief study of the cases will demonstrate the wide divergence of opinion on what constitutes a fair allowance and the complete unpredictability of what the allowance will be in a particular case. The Circuit Court of Appeals for the Seventh Circuit has given a clear dictum that allowances made in the discretion of the court are not accruable prior to the court's action.

On the other hand the bankrupt in $I n$ re Browm, ${ }^{93}$ was acting as receiver under appointment of an Indiana state court at time of bankruptcy. Ultimately, after bankruptcy, he received an allowance from the Indiana court of $\$ 1,265$ as compensation for his services as receiver. The services having been found to have been rendered twothirds prior to the filing of the bankruptcy petition and one-third thereafter, the second circuit awarded to the trustee in bankruptcy two-thirds of the fee. This case appears to be some authority for accruing receivers' fees.

\section{Conclusions}

The requirement that "accruals" be superimposed on the decedent's normal cash income for the year of death and thus subjected to tax at the highest possible rates is a harsh one. It, therefore, appears probable that the courts will tend to limit accruals under Section 42 to those which can be computed on a straight time-elapsed basis and will tend to reject as "accruals" estimates of such things as attorneys' fees, executors' and trustees' commissions and receivers' fees.

92. Ibid.

93. 4 F. (2d) 806 (C. C. A. 2d, 1924). 
If Section 42 is narrowed in this way, it seems likely that the Supreme Court will uphold it. The Section as so construed would tax only "income" (disregarding a slight confusion as to the period of computation), and perhaps the classification of the accounting period and the inclusion of accruals on a time-elapsed basis is neither too arbitrary nor too capricious. The Court as today constituted can certainly be expected to go a long way in allowing Congress full power over things which can be made to appear as matters of tax procedure and administration.

On the other hand, if the courts do uphold the commissioner in putting what in reality is income for a number of future years into one return on the theory that an estimate of future receipts warrants an "accrual", severe inequities will result in many cases. The elimination of the part of the statute causing these severe inequities would not seriously affect the scheme of the present law. Accruals to date of death are now subject to the estate tax; and if Congress preferred to subject such items to income tax instead, it could eliminate accruals from the estate tax law and under the income tax law provide that an estate should continue reporting on the same basis, cash or accrual, as the decedent used in his lifetime. Thus no income would escape income tax. Perhaps Congress could subject accruals to estate tax or income tax in the alternative-whichever would in a particular case produce the greatest revenue. The new Section 42 made an outright attempt to get a double tax on accruals at date of death-estate tax and income tax, but the tax derived cannot represent an impressive item in the aggregate of the tax revenues. The problem arises only once in the history of each individual taxpayer. If the Supreme Court should ultimately get a case involving drastic hardship, it is certainly within the range of possibility that it will find Congress has made an arbitrary and capricious classification and has attempted to levy an income tax on a nondescript, composite figure which is not "income" within the meaning of the Sixteenth Amendment. 